\title{
The Midwife's Role to Prevent Stunting in Selected Health Centers in Banyumas District 2015
}

\section{Aisyah Apriliciciliana Aryani ${ }^{1}$, Besral ${ }^{1}$, and Erna Kusumawati ${ }^{2}$}

${ }^{1}$ Postgraduate Student Faculty of Public Health, Universitas Indonesia, Depok, Indonesia

${ }^{2}$ University of Jenderal Soedirman, Purwokerto, Indonesia

\section{Abstract}

Midwives as health professionals have an essential role to prevent stunting, especially in pregnant women and children under two years. The purpose of this study was to determine the position of health center midwife in preventing stunting in 5 health centers in Banyumas district consisting of Karanglewas, Cilongok, Somagede, Sumbang, and Kembaran. This research was descriptive qualitative by using a sample comprising of five midwives, five pregnant women and five mothers of children aged 0-2 years. Data were collected by in-depth interview and used an instrument consisting of interview

Corresponding Author: Aisyah Apriliciciliana Aryani aisyaharyani93.aa@gmail.com

Received: 26 December 2018 Accepted: 23 February 2019 Published: 7 March 2019

Publishing services provided by Knowledge E

(c) Aisyah Apriliciciliana Aryani et al. This article is distributed under the terms of the

Commons Attribution License, which permits unrestricted use and redistribution provided that the original author and source are credited.

Selection and Peer-review under the responsibility of the $2 \mathrm{nd}$ International Meeting of Public Health 2016 Conference Committee.

\section{G OPEN ACCESS} guidelines, sound and image recording devices. The analysis included data reduction, data presentation, and conclusion. Results from this study were the role of midwives to pregnant women as an effort to prevent stunting include antenatal care that contains Upper Arm Circumference measurement, weight, and length body measurement, blood pressure measurement, supplementary feeding to pregnant women whose chronic energy deficiency and provision of iron tablets. While in children aged of 0-2 years, midwife never measured the length of the body because they did not have a microtome in health centers and also because they coud not measure the length of the body accurately. The conclusion of this study was the role of the midwife in preventing stunting in pregnant women had been good whereas in children aged of 0-2 years had not been good enough because they never measure the length-body routinely.

Keywords: Midwife; stunting; pregnant women; children under two years

\section{Introduction}

Stunting is a nutritional problem faced by Indonesia and found at many levels in society (WHO 2014). Globally stunting affects 162 million children under five years of age. The prevalence of stunting in Indonesia in 2007, 2010 and 2013 was 36.8\%, 35.6\% and 37.2\% (Riskesdas 2013). There was a significant increase in 2013compared with 2007 and 2010. In Central Java province, the prevalence of stunting increased by 1.1\%, which is 2010 amounted to $35.6 \%$ and in 2013 to $36.7 \%$ (The Ministry of Health 2013). The percentage 
of $36.7 \%$ consisted of $19.9 \%$ of short children and $16.8 \%$ of very short children.. In 2015 , Banyumas District Health Office reported that there was an increasing number of cases of stunting in 2014 which reached $17.49 \%$.

The data indicate that the prevalence of stunting remains to suppress. One effort that can be done is to prevent an increase in the number of cases of stunting through improved nutrition in the first thousand days period of life, which is 270 days during pregnancy and 730 days in the presence of the first babies born (Bappenas 2012).

Prevention of stunting can be done from the scope of the family up to the healthcare professional. Nutritionist in Health Center is one of the health workers who is expected to participate in reducing the prevalence of stunting. The Minister of Health Regulation Number 75 of 2014 concerning Community Health Center states that every health center was supposed to have one nutritionist. However, based on a preliminary survey, researchers found that there were nine health centers in Banyumas consisting of Kembaran II, Cilongok II, Karanglewas, Somagede, West Purwokerto, North Purwokerto I, East Purwokerto II, Sokaraja I and Sumbang I that did not have a nutritionist. In these circumstances, the midwife took over the nutritionist role and experienced a double burden which she not only did midwifery care but also required to perform various primary activities nutrition programs based on minimum service standards and consisted of monitoring the growth of children, the provision of nutritional supplements, nutrition services, nutritional counseling balanced and systems dietary vigilance $(\mathrm{MoH}, 2008)$.

Nutritional Status Monitoring (NSM) Toddler Banyumas 2014 showed that nine health centers mentioned above had a higher prevalence of stunting were Kembaran II, amounted to $19.16 \%$, Cilongok II amounted to $10.18 \%$, Karanglewas amounted to $21.7 \%$, Somagede amount to 9, 10\%, West Purwokerto amount to 3.76\%, North Purwokerto I amount to $5.41 \%$, East Purwokerto II amount to 0,16\%, Sokaraja I amounted to $2.88 \%$ and Sumbang I amounted to $16.18 \%$. The absence of nutritionist and the persistence of the prevalence of stunting in the nine health centers lead researchers interested in studying the role of midwives in the prevention of stunting in the selected health centers in Banyumas 2015.

\section{Methods}

This study was a qualitative descriptive study using in-depth interviews. The instrument used consisted of interview guidelines and sound and image recording devices. The sample used in this study included five midwives, five pregnant women, and five mothers of children aged 0-2 years. The method used in the selection of the sample was 
purposive sampling where if the time of data collection no longer found the varied information, researchers no longer needed to search for new information and information retrieval process was considered completed (Sugiyono 2009).

The midwives were midwives in Karanglewas, Cilongok II, Somagede, Sumbang I and Kembaran II. One midwife was selected as the center midwife because during data collection with in-depth interviews, the answers from all the midwives did not include varied thus the researcher did not continue with data collection for the other four midwives. The validity of the study was checked with triangulation by comparing the results of the interviews of a center midwife, pregnant women, and mothers of children aged 0-2 years.

\section{Results}

\subsection{Characteristics of study informants}

TABLE 1: Characteristics of Informants.

Name
Midwife 1
Midwife 2
Midwife 3
Midwife 4
Midwife 5
Pregnant Woman 1
Pregnant Woman 2
Pregnant Woman 3
Pregnant Woman 4
Pregnant Woman 5
Mothers of children aged $0-2$ years 1
Mothers of children aged 0 -2 years 2
Mothers of children aged 0-2 years 3
Mothers of children aged 0-2 years 4
Mothers of children aged 0-2 years 5

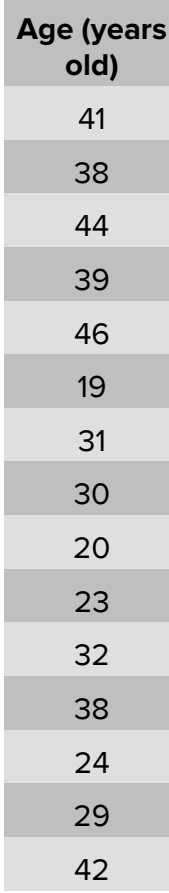

Last Education
D3 Midwifery
D1 Midwifery
D3 Midwifery
D3 Midwifery
D4 Midwifery
Junior High School
Elementary School
Junior High School
Junior High School
Junior High School
Senior High School
Elementary School
Junior High School
Junior High School
Elementary School

Based on Table 1, midwife 2 was the youngest (38 years old), while the midwife 5 was the oldest (46 years old). In pregnant women, the youngest age was19 years old, and the most past was 31 years old. Among mothers, the youngest was 24 years old, and the oldest was 42 years old. 
Three midwives graduated from D3 Midwifery (3-year program associate degree), one person graduated from D1 Midwifery (1-year program associate degree), and one person graduated from Midwifery D4 (4-year program associate degree). Among pregnant women, four people graduated from junior high school and one person graduated from elementary school. Among mothers of children aged 0-2 years, two people graduated from elementary school, two people graduated from junior high school, and one person graduated from high school.

\subsection{Role of midwives in preventing stunting in pregnancy}

TABLE 2: Antenatal Care and Feeding On Pregnant Women with Chronic Energy Deficiency.

\begin{tabular}{|c|c|}
\hline Role of Midwives & Measurement Method \\
\hline \multicolumn{2}{|l|}{ Antenatal Care } \\
\hline a. Weighing & $\begin{array}{l}\text { Pregnant woman standing on the scales and } \\
\text { then look at the scales located in any number }\end{array}$ \\
\hline b. Height Measurement & $\begin{array}{l}\text { Done in a standing position by using a } \\
\text { microtome }\end{array}$ \\
\hline c. Measurement of Blood Pressure & $\begin{array}{l}\text { Performed on pregnant mother's arm using a } \\
\text { sphygmomanometer }\end{array}$ \\
\hline d. Iron Tablet Supplementation & $\begin{array}{l}\text { Given directly to the pregnant woman during } \\
\text { antenatal }\end{array}$ \\
\hline e. Upper Arm Circumference Measurements & $\begin{array}{l}\text { Presented on the left wing of pregnant } \\
\text { women using MUAC tape }\end{array}$ \\
\hline $\begin{array}{l}\text { Additional food to pregnant women chronic } \\
\text { energy deficiency such as milk and biscuits }\end{array}$ & $\begin{array}{l}\text { Given directly to pregnant women as much as } \\
24 \text { packets of biscuits and one carton of milk } \\
\text { of pregnant women }\end{array}$ \\
\hline
\end{tabular}

Table 2 showeed how the midwives perform antenatal care and feeding on pregnant women with chronic energy deficiency.

\subsection{Role of midwives in preventing mother had stunting in children aged of $0-2$ years}

\section{Discussion}

\subsection{Role of midwives in preventing stunting in pregnancy}

All the midwives stated that the measurement of height and weighing aimed to determine the nutritional status of pregnant women, in which the nutritional status would affect fetal development. Research conducted by Yongki (2009) stated the same thing, in which the nutritional status of pregnant women was one of the factors that determine fetal growth and development, including infant weight and length at birth. 


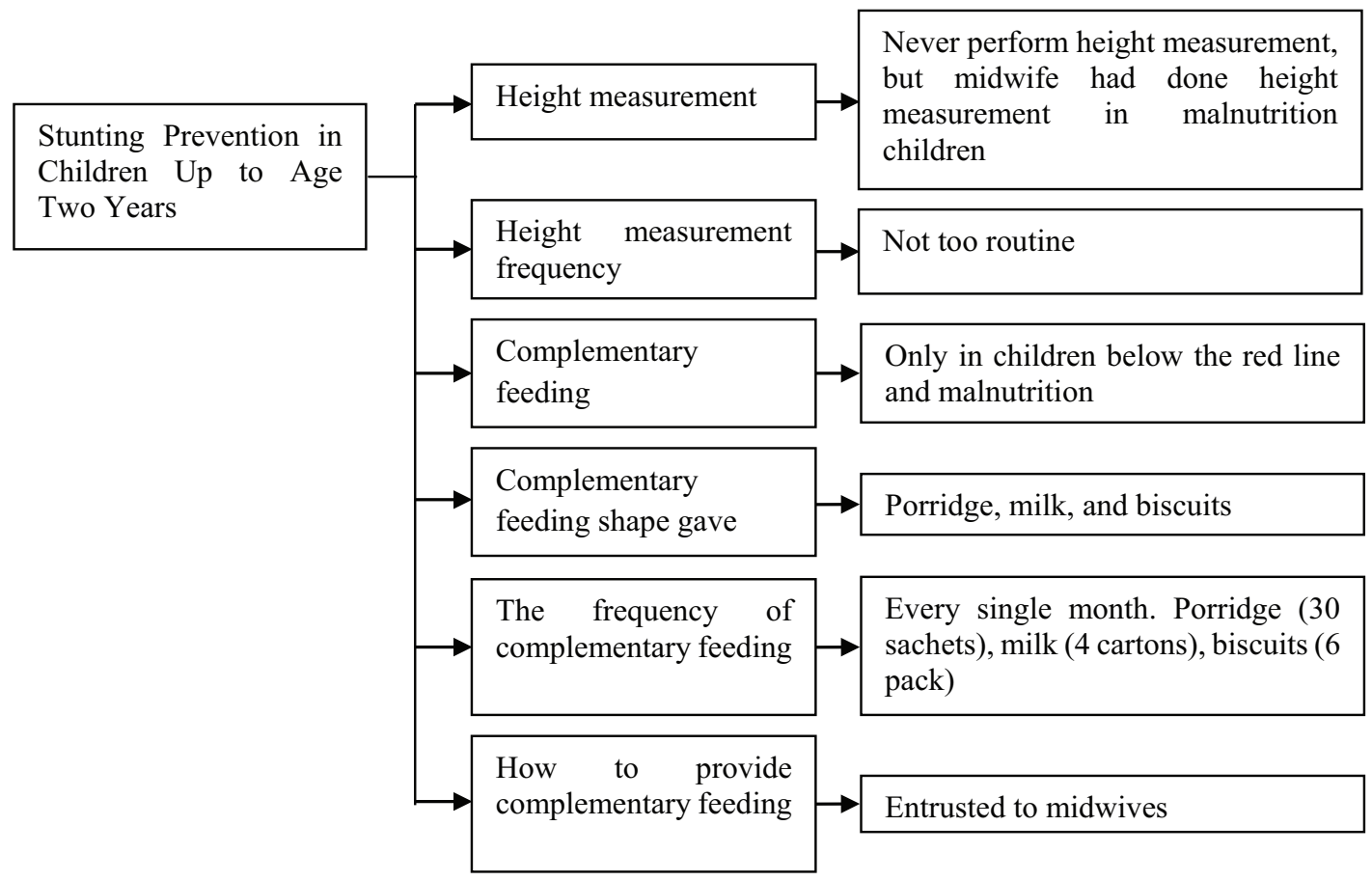

Figure 1: Role of Midwives in Preventing Stunting in Children Up to Age Two Years.

Supariasa (2012) stated that the measurement of Upper Arm Circumference is a method used to determine whether pregnant women suffered from chronic energy deficiency (CED) or not. Pregnant women indicated CED if the results obtained were less than $23.5 \mathrm{~cm}$ and when the measurement results of more than $23.5 \mathrm{~cm}$ in pregnant women was not reported CED. In addition to taking the measurements Upper Arm Circumference, a midwife had been working to overcome CED through supplementary feeding. Nurmadinisia (2015) stated that supplemental food to pregnant women with CED was sufficient to increase the weight of pregnant women. Research conducted by Siagian (2010) indicated that CED was one risk factor for having a baby of low birth weight. Blood pressure measurements performed by midwives during aimed to prevent preeclampsia which according to Vitartika (2014). One risk factor for LBW babies was born pre-eclampsia. Nasution (2014) mentioned that LBW babies were at higher risk of becoming stunting. Almatsier (2005) stated that the anemia due to iron deficiency might be a risk factor for the occurrence of stunting. Therefore, the current program, by giving blood tablets, is already in the right direction of stunting prevention. 


\subsection{Role of midwives in preventing mother had stunting in children aged of $0-2$ years}

All midwives stated that during the measurement of body length in children aged of 0 2 years have not been routinely performed both in health centers and neighborhood health center during the height measurement was only performed on children under five suffering from malnutrition. The cause was lack of tools, such as microtome that caused measurement results to become inaccurate. Another reason was in measuring the body's length because children aged 0-2 years tended to be fussy during measurement of body length. According to the Ministry of Health (2010), the analysis of body length had not been routinely performed since it had several drawbacks such as the difficulty in measuring the height at the age group of infants, unable to describe the state of nutrition today, requiring age data, which was often difficult to obtain in developing countries, often encountered errors in measuring scale reading, mainly when performed by non-professional personnel.

Department of Nutrition and Maternal and Child Health (2014) stated that an effort to prevent stunting was giving complementary foods for children older than six months. However, the respondents admitted that during that time, it was only complementary foods given to infants under the red line or suffering from malnutrition to prevent a decrease in nutritional status. Respondents also reported that breast milk was carried so far only in the form of porridge, milk or biscuits. They gave complementary feeding conducted by entrusting to the village midwife. This was due to the distance away to the house of children under five suffering from malnutrition or under the red line.

\section{Conclusion}

The conclusion of this study was the role of midwives in 5 selected health centers was good, but the purpose of a midwife to prevent stunting in children aged 0-2 years was not good enough. This was because a health center midwife had never done a body length measurements of children aged 0-2 years routinely.

\section{References}

[1] Almatsier, S. 2005. Basic Principles of Nutrition. Jakarta: Gramedia Pustaka Utama.

[2] Department of Nutrition and Maternal and Child Health. 2014. Training Facilitator Guide Module Counseling: Feeding Infants and Children. Jakarta: Ministry of Health. 
[3] Ministry of Health. 2008. Minimum Service Standards Health Center. Jakarta: DG of Community Health.

[4] Ministry of Health. 2013. Report of the Health Research Board, 2013. Jakarta: Health Research Development.

[5] Nasution, D. 2014. Relationships low birth weight (LBW) with Genesis Stunting At the age of 6-24 months in the city of Yogyakarta. Thesis. Yogyakarta: Study of the Graduate Program in Public Health, University of Gajah Mada.

[6] National Development Planning Agency (Bappenas). 2012. Nutrition Policy Framework Conscious Movement in the framework of a Thousand Day One Life (1000 HPK). Jakarta: The Ministry of Health of the Republic of Indonesia.

[7] Nurmadinisia, R. 2015. The effectiveness of Supplementary Feeding Program Maternal Chronic Energy Deficiency in Depok. Essay. Faculty of Medicine and Health Sciences. Jakarta: Public Health Study Program, UIN Syarif Hidayatullah.

[8] Sugiyono. 2009. Qualitative and Quantitative Research Methods R \& D. Bandung: Alfabeta

[9] Supariasa, I. D. N, Bakri, B., and Dawn, I. 2012. Nutritional Status Assessment. Jakarta: Book Medical Publishers EGC.

[10] Vitartika, A. 2014. Relationship Between Preeclampsia LBW in hospitals Karanganyar (Period 1 January to 31 December 2010). Essay. Solo: Faculty of Medicine, University of Muhammadiyah Surakarta.

[11] WHO. 2014. WHA Global Nutrition Target 2025: Stunting Policy Brief accessed March 29, 2015. http://www.who.int/nutrition/topics/globaltargets_stunting_policybrief.pdf. 